\author{
Multidisciplinary Journal \\ Journal homepage: https://jurnal.unej.ac.id/index.php/multijournal
}

\title{
Hubungan Intake Protein dengan Status Gizi pada Remaja Puteri
}

\author{
The Relationship of Protein Intake with Nutritional Status (Basal Metabolic Index) in Adolescent Girls
}

\author{
Talitha Zulis Islaamy ${ }^{1}$, Ristya Widi Endah Yani $^{2}$, Farida Wahyu Ningtyias ${ }^{3}$ \\ ${ }^{1}$ Pascasarjana Ilmu Kesehatan Masyarakat Universitas Jember \\ ${ }^{2}$ Program Studi Ilmu Kedokteran Gigi Universitas Jember \\ ${ }^{3}$ Program Studi Ilmu Kesehatan Masyarakat Universitas Jember \\ Email: talithazulis20@gmail.com \\ Artikel Diterima: DD MM 2020 . Proses Submit: , Revisi: 2020.
}

\begin{abstract}
Pada usia remaja pelajar lebih mementingkan penampilan fisik. Remaja putri termasuk kelompok yang rentan mengalami masalah gizi. Asupan makan yang buruk menjadi penyebab umum masalah gizi pada remaja. Keseimbangan antara zat gizi yang masuk dibutuhkan untuk kesehatan yang optimal. Penelitian ini menggunakan desain cross sectional yang bertujuan untuk mengetahui hubungan asupan protein dan status gizi pada remaja putri. Pengambilan data variabel intake protein menggunakan form food recall 24 jam. Pengambilan data variabel status gizi menggunakan pengukuran berat badan dengan timbangan digital analitik dan pengukuran tinggi badan menggunakan microtoa. Sampel yang digunakan adalah 40 siswa remaja putri di MA Mambaul Khoiriyatil Islamiyah. Uji statistik yang digunakan adalah uji Chi Square. Persentase responden dengan asupan protein kurang sebesar 90\%. Kesimpulan penelitian ini adalah terdapat hubungan yang signifikan antara asupan protein dengan status gizi dengan nilai $p$ value sebesar $0,035(<0,05)$.
\end{abstract}

\section{Kata Kunci: Intake Protein, Status Gizi, Remaja Puteri}

Abstrack. At the age of teenagers, students are more concerned with physical appearance. Adolescent girls are a group that is vulnerable to nutritional problems. Poor food intake is a common cause of nutritional problems in adolescents. A balance between the nutrients that enter is needed for optimal health. The data used in this study is a cross sectional design which aims to determine the relationship between protein intake and nutritional status in adolescent girls. Data collection on protein intake variables used a 24-hour food recall form. Data were collected on nutritional status variables using weight measurement with analytical digital scales and height measurements using microtoa. The sample used was 40 female students at MA Mambaul Khoiriyatil Islamiyah. The statistical test used is the Chi Square test. The percentage of respondents with less protein intake is $90 \%$. The conclusion of this study is that there is a significant relationship between protein intake and nutritional status with a $\mathrm{p}$ value of $0.035(<0.05)$.

Keywords: Protein Intake, Nutritional Status, Adolescent Girls

\section{Pendahuluan}

Remaja adalah kondisi peralihan dari masa anak-anak menuju dewasa. Pada masa ini para remaja mengalami perubahan fisik seperti penambahan tinggi badan hingga $25 \mathrm{~cm}$, perubahan bentuk tubuh dan masa menstruasi, bagi remaja putri, daya tarik seksualitas merupakan faktor yang kuat dan berpengaruh dalam kehidupannya ${ }^{1}$.

Remaja termasuk kelompok yang rentan mengalami berbagai masalah gizi seperti gizi kurang maupun gizi lebih ${ }^{2}$. Seiring dengan peningkatan populasi remaja di Indonesia, masalah gizi remaja perlu mendapatkan perhatian khusus karena berpengaruh terhadap pertumbuhan dan perkembangan tubuh serta dampaknya pada masalah gizi dewasa ${ }^{3}$. Status gizi seseorang menunjukkan seberapa besar kebutuhan fisiologis individu tersebut telah terpenuhi ${ }^{4}$. Keseimbangan antara gizi yang masuk dan gizi yang dibutuhkan untuk kesehatan optimal adalah penting. Saat kebutuhan gizi seseorang tercukupi untuk menyokong kebutuhan tubuh sehari-hari dan setiap peningkatan kebutuhan metabolisme, maka individu tersebut akan mencapai status gizi yang optimal ${ }^{5}$. Saat ini di Indonesia prevalensi kurus pada remaja usia 16-18 tahun prevalensi kurus sebesar $(9,4 \%)$ dan prevalensi gemuk sebesar $(7,3 \%)^{6}$.

Sebagian besar remaja puteri $(67,8 \%)$ memiliki frekuensi makan kurang dari $3 \mathrm{kali}^{7}$. Ketidakseimbangan konsumsi kebutuhan zat gizi pada dasarnya berawal dari pemahan yang keliru dan perilaku gizi yang salah sehingga dapat menimbulkan masalah gizi pada remaja ${ }^{8}$.

Tujuan dari penelitian ini adalah untuk mengetahui hubungan antara intake protein dan status gizi pada remaja puteri di MA Mambaul Khoiriyatil Islamiyah Kecamatan Bangsalsari Kabupaten Jember.

\section{Bahan dan Metode}

Penelitian ini termasuk dalam penelitian observational analitik dengan desain cross sectional. Uji statistik yang digunakan adalah analisis uji chi square. Penelitian ini digunakan untuk menganalisis faktor hubungan antara intake protein dan status gizi pada remaja puteri di MA MHI Kecamatan Bangsalsari 
Kabupaten Jember. Variabel independen pada penelitian ini adalah intake protein dan variabel dependen pada penelitian ini adalah status gizi pada remaja putri.

\section{Waktu dan Tempat}

Waktu penelitian terhitung sejak bulan September - Oktober 2019. Penelitian ini dilakukan di MA MHI di wilayah kerja Puskesmas Bangsalsari Kabupaten Jember.

\section{Bahan dan Alat}

Instrumen yang digunakan dalam penelitian ini adalah kuesioner form food recall untuk variabel intake protein. Pengukuran status gizi yaitu mengukur berat badan menggunakan timbangan digital analitik dan tinggi badan menggunakan microtoa.

\section{Prosedur Penelitian}

Prosedur penelitian dalam penelitian ini adalah sebagai berikut :

1. Tahap konseptual (merumuskan dan memgidentifikasi masalah, meninjau kepustakaan yang relevan, mendefinisikan kerangka teoritis, merumuskan hipotesis).

2. Fase perancangan dan perencanaan (memilih rancangan penelitian, mengidentifikasi populasi yang diteliti, mengkhususkan metode untuk mengukur variable penelitian, merancang rencana sampling, mengakhiri dan meninjau rencana penelitian, melaksanakan penelitian dan melakukan revisi).

3. Membuat instrumen dan pengumpulan data penelitian.

4. Fase empirik (pengumpulan data, persiapan data untuk di analisis) mengumpulkan data penelitian yang telah dilaksanakan di lapangan.

5. Fase analitik (menganalisis data dan menghitung hasil data penelitian), mengolah dan mengalisis data hasil penelitian. Data yang telah dikumpulkan dari lapangan diolah dan dianalisis untuk mendapatkan kesimpulankesimpulan yang diantaranya kesimpulan dari hasil pengujian hipotesis penelitian.

6. Fase diseminasi (mendesain hasil penelitian). Pada tahap akhir, agar hasil penelitian dapat dibaca, dimengerti, dan diketahui oleh pembaca maka hasil penelitian tersebut disusun dalam bentuk kesimpulan dari hasil penelitian.

Analisis data yang digunakan dalam penelitian ini merupakan analisis uji chi square yang dianalisis menggunakan SPSS.

Karakteristik Responden

Tabel 1. Distribusi Frekuensi Umur, Pendapatan Keluarga, dan Uang Saku.

\begin{tabular}{lcc}
\hline \multicolumn{1}{c}{ Variabel } & Jumlah(n) & $\%$ \\
\hline Karakteristik Responden & & \\
\hline Umur & 40 & 100
\end{tabular}

\begin{tabular}{|c|c|c|}
\hline Total & 40 & 100 \\
\hline \multicolumn{3}{|l|}{ Pendapatan Keluarga } \\
\hline Rendah & 39 & 97,5 \\
\hline Sedang & 1 & 2,5 \\
\hline Tinggi & 0 & 0 \\
\hline Sangat Tinggi & 0 & 0 \\
\hline Total & 40 & 100 \\
\hline \multicolumn{3}{|l|}{ Uang Saku } \\
\hline Rp 2.500/hari - Rp 5.000/hari & 31 & 77,5 \\
\hline Rp 6.000/hari - Rp 10.000/hari & 9 & 22,5 \\
\hline $\operatorname{Rp} 11.000 /$ hari $-\operatorname{Rp} 15.000$ /hari & 0 & 0 \\
\hline $\operatorname{Rp} 16.000 /$ hari $-\operatorname{Rp} 20.000 /$ hari & 0 & 0 \\
\hline $\operatorname{Rp} 25.000 /$ hari $-\operatorname{Rp} 50.000 /$ hari & 0 & 0 \\
\hline Total & 40 & 100 \\
\hline
\end{tabular}

Diketahui bahwa responden memiliki rentang usia 16-18 tahun. Selain itu, pendapatan keluarga juga cenderung rendah $(97,5 \%)$ dan uang saku responden mayoritas $\leq \mathrm{Rp}$ 5.000/hari sebanyak $(77,5 \%)$.

\section{Hasil dan Pembahasan 3.1. Hasil}

Pengetahuan Gizi

Tabel 2. Distribusi Frekuensi Intake Protein

\begin{tabular}{|c|c|c|}
\hline Pengetahuan Gizi & $\mathrm{n}$ & $\%$ \\
\hline Kurang & 36 & 90 \\
\hline Cukup & 4 & 10 \\
\hline Total & 40 & 100 \\
\hline
\end{tabular}

Diketahui bahwa mayoritas responden memiliki intake protein kurang $(90 \%)$ yaitu 36 responden, dan responden dengan intake cukup $(10 \%)$ yaitu 4 responden.

\section{Status Gizi}

Tabel 3. Status Gizi (IMT/U) Responden

\begin{tabular}{lcl}
\hline \multicolumn{1}{c}{ Status Gizi (IMT/U) } & $\mathrm{n}$ & $\%$ \\
\hline Gizi Buruk (Severely thinnest) & 20 & 50 \\
Gizi Baik (Normal) & 20 & 50 \\
\hline Total & 40 & 100 \\
\hline
\end{tabular}

Diketahui bahwa responden status gizi buruk (50\%) yaitu 20 responden, status gizi baik (50\%) yaitu 20 responden.

Tabel 4. Hasil Analisis Chi Square

\begin{tabular}{|c|c|c|c|c|}
\hline \multirow{2}{*}{$\begin{array}{c}\text { Variabel } \\
\text { Independen }\end{array}$} & \multicolumn{2}{|c|}{ Status Gizi } & \multirow[t]{2}{*}{ Total } & \multirow[t]{2}{*}{$p$-value } \\
\hline & Buruk & Baik & & \\
\hline \multicolumn{5}{|l|}{ Intake Protein } \\
\hline Buruk & 20 & 16 & 36 & 0,035 \\
\hline Sedang & 0 & 4 & 4 & \\
\hline Total & 20 & 20 & 40 & \\
\hline
\end{tabular}

Diketahui bahwa hasil analisis uji chi square dengan $p$ value 0,035 yang berarti ada hubungan yang signifikan antara variabel intake protein dengan status gizi pada remaja puteri.

\subsection{Pembahasan}

a. Karakteristik Responden

Hasil penelitian ini didapatkan paling banyak responden adalah remaja berumur 16 tahun. Pendapatan keluarga cenderung rendah sebesar 97,5\% yaitu dengan rata-rata penghasilan keluarga sebesar $\mathrm{Rp} 1.167 .500,00$ per bulan. Berdasarkan penggolongan besaran penghasilan menurut Badan Pusat Statistik golongan pendapatan rendah adalah jika rata-rata 
penghasilan sebesar $\leqslant$ Rp $1.500 .000,00$ per bulan ${ }^{10}$. Uang saku responden mayoritas dengan kriteria rendah yaitu sebesar Rp 2.500 - Rp 5.000,00 per hari sebanyak (77,5\%) dengan rata-rata sebesar $\mathrm{Rp} 5.475,00$ per hari.

Uang saku yang digunakan untuk membeli makanan jajanan di sekolah rata-rata sebesar Rp 2.000,00 - Rp 5.000,00, dengan jumlah uang saku untuk membeli jajan minimal $\mathrm{Rp}$ 5000,00 dan maksimal Rp 10.000,00. Rata-rata uang saku siswa antara $\mathrm{Rp} 2.000$ hingga $\mathrm{Rp} 10.000^{12}$. Mayoritas responden memiliki uang saku sebesar Rp 5.000 untuk jajan setiap hari. Tersedianya uang saku yang cukup dapat meningkatkan daya beli responden terhadap makanan dari luar pondok pesantren.

\section{c. Intake Protein}

Seluruh responden tetap mengonsumsi makanan sumber protein setiap hari, namun berdasarkan jumlah asupan masih kekurangan protein. Protein adalah mineral makro yang berfungsi sebagai sumber energi, zat pembangun tubuh, dan zat pengatur di dalam tubuh ${ }^{11}$. Penelitian lain yang dilakukan menunjukkan bahwa persentase remaja umur 16-18 tahun yang mengalami kekurangan asupan protein sebesar $35,6 \%{ }^{12}$. Hal ini menunjukkan bahwa masih banyak remaja yang mengalami kekurangan asupan protein. Kekurangan protein bila berlangsung lama dapat mengakibatkan pertumbuhan dan perkembangan jaringan yang tidak normal, kerusakan fisik dan mental, dan anemia ${ }^{13}$.

\section{d. Status Gizi}

Status gizi anak dapat dipengaruhi oleh tingkat penghasilan, tingkat pendidikan dan pengetahuan dari orangtua tentang makanan yang bergizi ${ }^{15}$. Status gizi menggambarkan keadaan gizi seseorang pada saat tertentu sehingga dapat digunakan untuk menentukan apakah mengalami keadaan gizi yang baik atau buruk. Rata-rata orangtua responden berpenghasilan rendah dengan tingkat pendidikan terakhir SD/sederajat. Pola makan akan mempengaruhi Tinggi badan dan berat badan, pola makan ataupun diit yang salah akan mengakibatkan pertumbuhan pada remaja tidak optimal.

e. Hubungan Intake Protein dengan Status Gizi (IMT/U) pada Remaja Puteri

Hubungan antara asupan protein dan status gizi $(\mathrm{p}=0,035)$ memiliki hubungan yang signifikan positif. Hal ini juga menunjukkan bahwa bila terjadi kenaikan asupan protein maka akan terjadi peningkatan status gizi, dan sebaliknya. Hasil ini sejalan dengan penelitian yang dilakukan di Asrama Putri Pondok Pesantren Al-Islam Nganjuk yang menyatakan ada hubungan yang signifikan antara tingkat kecukupan protein dengan status gizi ${ }^{15}$. Pemeitian lainnya yang dilakukan di FKM Unhas Makassar yang menyebutkan bahwa ada korelasi positif antara tingkat kecukupan karbo-hidrat dengan status gizi ${ }^{16}$. Pada remaja perlu upaya untuk menjaga status gizi agar selalu berada dalam kondisi yang optimal yaitu dengan berpedoman pada gizi seim-bang, dimana mengonsumsi makanan sesuai dengan porsi masing-masing individu dan menghindari ketidakseimbangan an-tara zat gizi $^{17}$.

\section{Kesimpulan}

Responden sebagian besar berusia 16 tahun dengan tingkat pendidikan orang tua mayoritas pendidikan dasar. Rerata pendapatan keluarga tergolong rendah. Uang saku mayoritas siswa $<5000 /$ hari. Hasil uji statistik menunjukkan bahwa terdapat hubungan antara intake protein dengan status gizi pada siswa remaja puteri.

\section{Saran}

Perlu meningkatkan asupan protein dengan menerapkan pedoman gizi seimbang agar asupan yang dimakan sesuai dengan perkembangan tumbuh kembang dan status gizi pada siswa remaja puteri.

\section{Ucapan Terima Kasih}

Terima kasih kepada seluruh siswa puteri MA MHI yang telah bersedia menjadi responden serta pihak guru yang telah berkenan memberikan ijin atas pelaksanaan penelitian ini.

\section{Acuan Referensi}

[1] Deshmukh, V.R. \& Kulkarni, A.A. Body image and its relation with body mass index among Indian Adolescent.

[2] Cunningham, K., Ruel, M., Ferguson, E., dan Uauy, R. Women's Empowerment and Child Nutritional Status in South Asia: a Synthesis of The Literature. Maternal Child Nutrition. 2015; 11(1): $1-19$.

[3] Washi, S.A. dan Ageib, M.B. Poor Diet Quality and Food Habits are related to Impaired Nutritional Status in 13-to 18-Year-Old Adolesccent in Jeddah. Nutrition Research. 2010; 30 (8): 527-534.

[4] Rampersaud, G.C., Pereira, M.A., Girard, B.L., Adams, J., Metzl, J.D. Breakfast Habits, Nutritional Status, Body Weight, and Academic Performance in Children and Adolescents. Elsevier. 2005; 105 (5): 743-760.

[5] Conde, W.L., dan Carlos, A.M. Body mass index cutoff points for evaluation of nutritional status in Brazilian children and adolescents. J Pediatr (Rio J). 2006; 82(4): 266-72.

[6] Riskesdas] Riset Kesehatan Dasar. Laporan Nasional Riset Kesehatan Dasar (Riskesdas) 2013. Badan Penelitian dan Pengembangan Kesehatan Depkes RI, Jakarta. 2013.

[7] Haq, A.B., Murbawani, E. Status Gizi, Asupan Makan Remaja Akhir yang Berprofesi Sebagai Model. Journal of Nutrition College. 2014; $3(4)$

[8] Zuhdy, Nabila. Hubungan Pola Aktivitas Fisik dan Pola Makan dengan Status Gizi pada Pelajar Putri SMA Kelas 1 di Denpasar Utara. Tesis. Universitas Udayana. Denpasar. 2015.

[9] Berge, J.M., Jin, S.W., Hannan, P., dan Sztainer, D.N. Structural and Interpersonal Charactersics of Family Meals: Association With Adolescent Body Mass Index and Diettary Pattern. Journal of The Academy of Nutrition and Dietetics. 2013; 113 (6): 816-822.

[10] Evans E.W., Jacques, P.F., Dallal, G.E., Sacheck, J., dan Must, A. The Role of Eating Frequency on Total Energy Intake and Diet Quality in a low Income, Racially Diverse Sample of Schoolchildren. Public Health Nutriton. 2015; 18 (3): 474-481.

[11 Dhillon, J., Craig, B.A. Leidy, H.J. Jacobs, A. Jones, B.L. Keeler, C.L. et al. (2016). The Effect of Increased Protein Intake on Fullness: A Meta Analysis and Its Limitations. Journal of the Academy of Nutrtion and Dietetics. 2016; 116 (6): 968-983.

[12] Choudhary, S., Saluja, N., Sharma, S., Dube, S., Pandey, M., dan Kumar, A. Association of Energy balance and Protein Intake with Nutritional Status of Adolescent Girls In a Rural Area of Haryana. Journal of Medical and Dental Sciences. 2015; 4 (1): 6-11.

[13] Wardlaw, G.M. \& Jeffrey, S. H. Perspectives in Nutrition. Seventh Edition. New York: McGraw Hill Companies Inc; 2007.

[14] Nishida, C. Appropriate body-mass index for Asian populations and its implications for policy and intervention strategies. The Lancet. 2004; 363: 157-163.

[15] Dewi, C.K. Hubungan Antara Tingkat Kecukupan Gizi (Energi, Protein, Vitamin A, Vitamin C dan Zat Besi) dengan Status Gizi Santriwati di Asrama Putri Pondok Pesantren AlIslam Kecamatan 
Sukomoro Kabupaten Nganjuk. The Indonesian Journal of Public Health. 2011; 9 (1):

[16] Muchlisa., Citrakesumasari., \& Indriasari, R. (2013). Hubungan Asupan Zat Gizi dengan Status Gizi pada Remaja Putri di Fakultas Kesehatan Masyarakat Universitas Hasanuddin Makassar Tahun 2013. Jurnal MKMI. 2013; 9 (3).

[17] Devi, N. Nutrition And Food Gizi Untuk Keluarga. Jakarta: PT Kompas Media Nusantara. 2010 [18] Indartanti, D. \& Kartini, A. 2014. Hubungan Status Gizi dengan Kejadian Anemia pada Remaja Putri. Journal of Nutrition College, 3(2) : 33-39. 